\title{
INTERCOMPARISON OF GAMMA CELL 220 IRRADIATOR FACILITIES AND DR. MIRZAN T RAZZAK GAMMA IRRADIATORS USING HARWELL DOSIMETERS
}

\author{
Bimo Saputro ${ }^{1}$, Fifi Nurfiana ${ }^{2}$, Sugili Putra ${ }^{3}$ \\ 1) Isotope and Radiation Application Center - BATAN \\ 2,3) Polytechnic institute of Nuclear Technology - BATAN
}

\begin{abstract}
ABSTRAK
Interkomparasi Fasilitas Iradiator Gamma Cell 220 dan Iradiator Gamma Dr Mirzan T Razzak Menggunakan Dosimeter Harwell. Iradiator gamma merupakan fasilitas multiguna yang dapat dimanfaatkan untuk pengawetan makanan, sterilisasi alat medis, rekayasa genetika dan proses polimerisasi. Pada fasilitas iradiasi gamma, dosis serap pada produk menjadi poin kunci pada proses. Standarisasi jaminan mutu produk diatur dalam Technical Document IAEA nomor 409 tentang Dosimetry for Food Irradiation, ISO 14470 Food Irradiation dan ISO 11137-3 mengenai Guidance on Dosimetric Aspects of Development, Validation and Routine Control. Dosis serap pada suatu fasilitas iradiasi dipengaruhi oleh pergerakan produk terhadap sumber, posisi sumber terhadap produk, besaran aktivitas radioaktif pada fasilitas dan laju dosis pada ruang iradiasi. Maka dari dilakukan uji peforma dosimeter dan sistem jaminan kualitas melalui teknik interkomparasi fasilitas. Interkomparasi berfungsi menguji dosimeter (alat ukur) pada 2 fasilitas yang berbeda untuk menentukan kinerja alat ukur. Interkomparasi dapat dilakukan pada minimal 2 fasilitas atau lebih. Pada penelitian ini, interkomparasi dilakukan pada 2 fasilitas iradiasi menggunakan dosimeter rutin merek harwell. Interkomparasi dilakukan pada rentang dosis 1 kGy hingga 30 kGy dengan 20 titik dosis. Dari hasil penelitian yang dilakukan, didapatkan simpangan tertinggi mencapai sebesar 19\% pada fasilitas Iradiator Gamma Cell 220 dan simpangan sebesar 21\% pada fasilitas Iradiator Gamma Dr Mirzan T Razzak. Hasil simpangan ini menjadi evaluasi untuk peforma dosimeter guna menentukan peforma akurasi dan presisi alat ukur dosis (dosimeter).
\end{abstract}

Kata kunci: Dosimeter, Dosis Serap, Iradiator Gamma, Interkomparasi

\begin{abstract}
The gamma irradiator is a multi-purpose facility that possibly used to preserve food, sterilize medical equipment, and conduct genetic engineering and polymerization processes, during which the absorbed dose of the product is critical. The standardization of product quality assurance was regulated by the IAEA Technical Document Number 409 considering Dosimetry for Food Irradiation and ISO 14470 and 11137-3 on Food Irradiation, as well as the Guidance on Dosimetric Aspects of Development, Validation, and Routine Control, respectively. The absorbed dose was influenced by the movement of the product to the source, its position, the amount of radioactive activity in the facility, and the dose rate in the irradiation room. The dosimeter performance test and quality assurance of the system were conducted using the Facility Intercomparison Technique which tested the dosimeter (measuring instrument) at 2 different facilities to determine the performance of the measuring instrument.. In this study, 2 irradiation facilities were tested using a Harwell routine dosimeter in the dose range of $1 \mathrm{kGy}$ to $30 \mathrm{kGy}$ and 20 dose points. The results showed that the highest deviation reached 19\% and 21\% at the Gamma Cell 220 and the Dr. Mirzan T Razzak Gamma irradiator facilities. This elevated the performance of the dosimeters to determine the precision accuracy of the dosemeasuring instrument.
\end{abstract}

Keywords: Absorb dose, dosimeter, gamma irradiator, intercomparison 


\section{INTRODUCTION}

There are 4 categories of gamma irradiators, including I, II, III, and IV [1]. Their nuclear installations use gamma radiation from a radioactive source, Cobalt-60 (Co-60), and upon targeting a material, they sterilize medical equipment and preserve food. In Indonesia, the use of gamma irradiation is regulated in the Head Regulation of Drug and Food Supervisory Agency on Food Packaging Supervision Number 3 of 2018 and an IAEA Technical Document Number 409 on Dosimetry for Food Irradiation that explains product standards, facilities, and quality assurance (irradiated dose dosimetry system).

From the 1950 s to the early 2000 s, there was a rapid growth of irradiator development, and this is expected to happen again based on the great potential of the gamma irradiator benefits in 2020. Furthermore, irradiation needs are supported by FAO, which shows that $25 \%$ of agricultural and food products are damaged by insects, bacteria, and other animals after harvest, and $40 \%$ of fruit products before reaching the market. In the irradiation process, quality assurance of irradiated products is fundamental, and it is ensured by administering the correct radiation dose to each product/sample. Therefore, a verification of the dosimetry system in an irradiation facility is critical. A dosimeter is a tool that measures the irradiation response [1], and it can be grouped into primary, reference, transfer, or routine categories. In previous studies, the intercomparison process was done using primary and secondary standard dosimeters at an international reference laboratory scale. However, this study used a routine standard dosimeter and aimed to assess the performance of the irradiator facility. This was to study the standard routine dosimetry on the category I of gamma irradiator using a routine dosimeter to guarantee that every irradiation process complies with quality standards.

\section{THEORY}

Gamma irradiator is a nuclear installation used to provide radiation intentionally and measurably. It has four categories, including I, II, III, and IV [1]. In category I, the source is stored in a dry container made of solid material that does not move (idle) as the sample to be irradiated moves. Figure 1 shows category I of gamma irradiator.

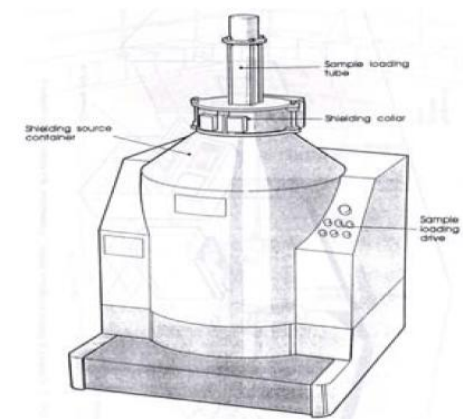

Figure 1. Category I of Gamma Irradiator.

Gamma irradiators probably use a radioactive Cobalt-60 source with an energy of $1.17 \mathrm{MeV}$ to $1.33 \mathrm{MeV}$ and a decay time of 5.27 years, or Cesium-137 with an energy of $0.662 \mathrm{MeV}$ and a decay time of 30.5 years. Cobalt-60 is utilized because it has a relatively long half-life (5.27 years) and is not easily soluble in water. Therefore, it is safe to store the Cobalt-60 source in a pool of water [6].

The International Organization of Standards (ISO) is a community/association of experts joined to set standards for a process applicable in various countries. ISO 14470 and 11137 on Food Irradiation Validation and Routine Control, and Irradiation Healthcare Products Validation and Routine Control, respectively, are applied to a facility, where each clause includes facility-physical, sourcesafety, security-monitoring, traceability, dose monitoring, and protection of irradiated products [2].

ISO 11137 also describes what is required to develop, validate, and run a routine control of the sterilization process of health products [3]. Its Part 3 outlines how a dose is measured, the maximum acceptable dose is determined, the sterile dose is established, installation and performance are assessed for qualification, and how a routine is monitored and controlled [5].

In the control process, a dosimeter is needed to measure the obtained dose. Table 1. shows the classification of dosimeters.

Table 1. Dosimeter Classification.

\begin{tabular}{clc}
\hline \multicolumn{1}{c}{ Class } & \multicolumn{1}{c}{ Dosimeter } & Uncertainty \\
\hline \multirow{2}{*}{ Primer } & $\begin{array}{l}\text { Calorimeter; } \\
\text { Ionization } \\
\text { Chamber }\end{array}$ & $1 \%$ \\
\hline \multirow{2}{*}{ Reference } & $\begin{array}{l}\text { Alanine ; } \\
\text { Dichromate; } \\
\text { Ethanol- }\end{array}$ & $2 \%-3 \%$ \\
\hline
\end{tabular}




\begin{tabular}{clc}
\hline Class & \multicolumn{1}{c}{ Dosimeter } & Uncertainty \\
\hline & Chlorobenzene & \\
& (ECB) ; Fricke & \\
& Alanine ; Fricke; & \\
Transfer & Ethanol- & \multirow{2}{*}{$3 \%-5 \%$} \\
& Chlorobenzene \\
& (ECB) & \\
\hline & PMMA ; & \\
& Radiochromic & \\
Routine & Film; CTA; & $=5 \%$ \\
& Ethanol- \\
& Chlorobenzene \\
& (ECB)
\end{tabular}

There are several levels of irradiation dosimetry systems according to different uncertainties [1]. The primary dosimeter is used by national standard laboratories, where the calorimeter and ionization chambers are the standards and only calibrated once during the instrument's lifetime, while the reference dosimeters are calibrated as a primary standard and are used to calibrate the lower ones. Moreover, the transfer dosimeter serves as a bridge between an accredited calibration laboratory and an irradiation facility and guides dosimeter traceability. In general, dosimeters are routinely used to map doses and run routine control. The irradiation dosimetry technique measures the absorbed dose of the product, which is the amount of ionizing radiation energy per unit mass of a particular material. In International Units (SI), it is expressed in $\mathrm{J} / \mathrm{kg}$, where the absorption value of $1 \mathrm{~J} / \mathrm{kg}$ is equivalent to 1 gray (Gy).

The density of the irradiated product/sample and the position of the maximum and minimum doses can be determined using a dosimeter experiment on a certain density test material or through computation. Although this method has the disadvantage of high nominal prices and takes a long time, its results are close to the actual ones. When using computation, the Monte-Carlo method is the most widely used [7].

\section{METHOD}

Irradiation was conducted at 2 facilities, specifically Dr. Mirzan T Razzak Gamma Irradiator in Yogyakarta and Gamma Cell 220 in Jakarta, using a Harwell Amber and Red Perspex dosimeters. The dose rate, activity during irradiation, humidity, and room temperature readings were recorded. A total of
2 Harwell Amber and 1 Red Perspex dosimeters were placed in the same room called gamma phantom, which created the same conditions for all of them. Dosimeter measurements were read on a UV-Vis spectrometer. The Harwell Amber dosimeter was measured between a wavelength of $603 \mathrm{~nm}$ and $651 \mathrm{~nm}$, while the Red Perspex one was at $640 \mathrm{~nm}$. After taking the readings at each wavelength, the thickness of each dosimeter was measured in $\mathrm{cm}$. By dividing the absorbance value by this value, specific absorbance was determined, and was converted to the absorbed dose value based on the calibration table.

\section{RESULTS AND DISCUSSION}

Irradiation occurred at 2 irradiator facilities, specifically the Gamma Cell 220 irradiator in Jakarta and Dr. Mirzan T Razzak in Yogyakarta, and used Harwell Amber and Red Perspex dosimeters made in England. The Harwell Amber dosimeter had a measurement range of 1-30 kGy, while the Red Perspex 5-50 kGy. Dosimeter measurements for Harwell Amber were read from a UV-Vis spectrometer at a wavelength of $603 \mathrm{~nm}$ in the dose range of 1-15 kGy, and $651 \mathrm{~nm}$ at 16-30 kGy. Moreover, Red Perspex used a wavelength of $640 \mathrm{~nm}$ at 5$50 \mathrm{kGy}$. In the first step, a specific absorbance response for dose analysis was performed, as shown by the graph in Figure 3.

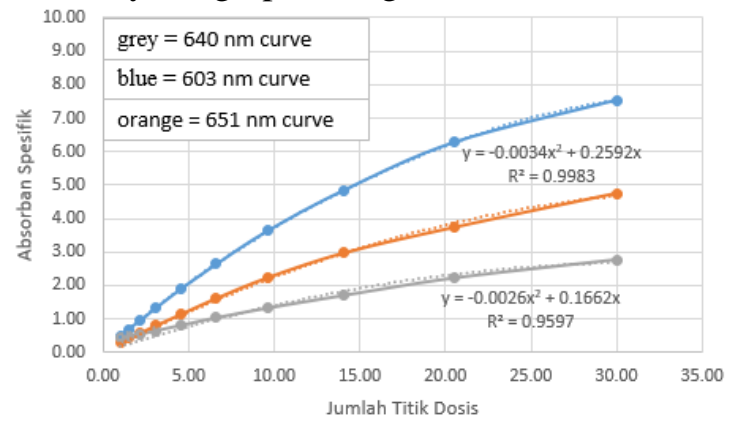

Figure 3. Specific Absorbant Response

According to Figure 3, the regression value is $\mathrm{R}=1$ for the $603 \mathrm{~nm}, \mathrm{R}=0.9983$ for $651 \mathrm{~nm}$, and $\mathrm{R}=0.9597 \mathrm{~nm}$ for the $640 \mathrm{~nm}$ curves in the dose range of 1-30 kGy. This shows that the specific absorbance value is linear with the absorbed dose.

A preliminary study was conducted on 27 August 2020 on the performance of the Harwell dosimeter at the Gamma Cell 220 Irradiator Facility in Jakarta, in which a dose 
rate of $4134 \mathrm{~Gy} /$ Hour and source activity of Co$605544 \mathrm{Ci}$ were used for irradiation. Figure 4 shows the experimental results of the absorbed dose-response dosimeter.

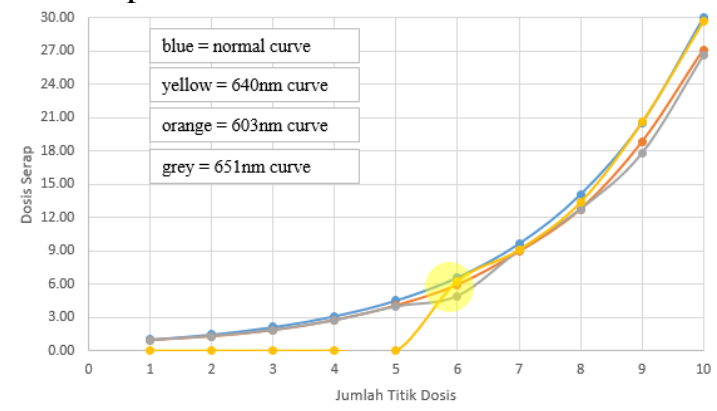

Figure 4. Absorbed Dose-Response

Based on Figure 4, the Harwell Amber dosimeter measurement readings at wavelengths of $603 \mathrm{~nm}$ and $651 \mathrm{~nm}$ had an error of $2 \%$ to $11 \%$ and the response at a $640 \mathrm{~nm} 1 \%$ to $5 \%$.

Based on the initial experiment results, an intercomparison was made at the Dr. Mirzan $\mathrm{T}$ Razzak facility in Yogyakarta on 17 September 2020 at $3400 \mathrm{~Gy} / \mathrm{Hour}$ dose rate, Co-60 activity of $8224 \mathrm{Ci}, 28^{\circ} \mathrm{C}$ temperature, and $59 \%$ humidity. The comparisons used 2 Harwell Amber and 1 Red Perspex dosimeters. Furthermore, irradiation was conducted in a dose range of 1-30 kGy with 20 dose points determined using the calculation of the number of decades to obtain a logarithmic dose point, as shown in Table 2.

Table 2. Dosage Point in kGy Units.

\begin{tabular}{cccc}
\hline No & Dose & No & Dose \\
\hline 1 & 1.00 & 11 & 5.99 \\
\hline 2 & 1.20 & 12 & 7.16 \\
\hline 3 & 1.43 & 13 & 8.57 \\
\hline 4 & 1.71 & 14 & 10.25 \\
\hline 5 & 2.05 & 15 & 12.26 \\
\hline 6 & 2.45 & 16 & 14.66 \\
\hline 7 & 2.93 & 17 & 17.53 \\
\hline 8 & 3.50 & 18 & 20.97 \\
\hline 9 & 4.19 & 19 & 25.08 \\
\hline 10 & 5.01 & 20 & 30.00 \\
\hline
\end{tabular}

Irradiation was carried out using gamma phantom to ensure temperature and humidity conditions remained homogenous. The results of the irradiation at Dr. Mirzan T Razzak's facility are shown in Figure 5.

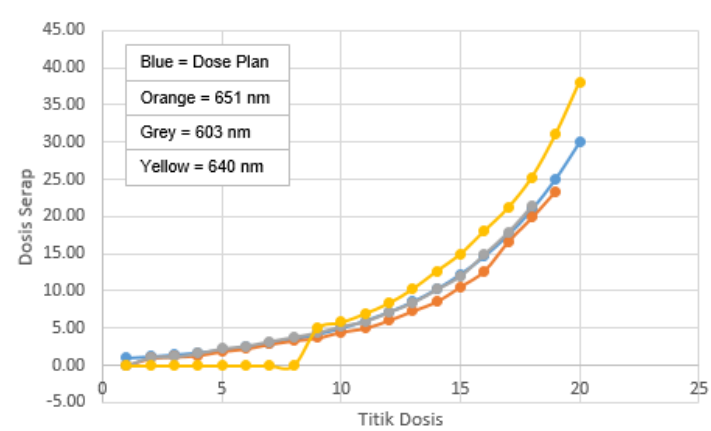

Figure 5. Results of irradiation at Dr. Mirzan T Razzak's facility.

Based on the graph, $651 \mathrm{~nm}$ wavelength measurement erred in the range of $1 \%$ to $21 \%$, and the large variations could have resulted from the distance between irradiation and measurement or humidity factors. The error ranges at the wavelength of $603 \mathrm{~nm}$ and 640nm were $3 \%$ to $11 \%$ and $16 \%$ to $27 \%$, respectively. The second experiment with the same method was conducted at the Gamma Cell 220 Irradiator Facility in Jakarta, and Figure 6 shows the results.

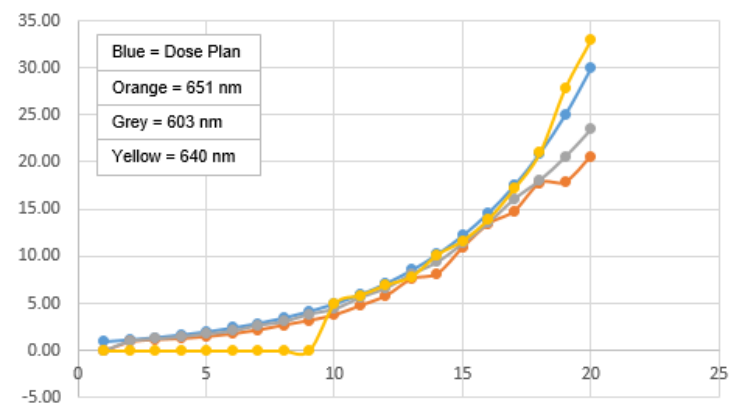

Figure 6. Gamma Cell 220 Facility irradiation results.

The facility dose rate was $4050 \mathrm{~Gy} / \mathrm{Hour}$ with Co-60 activity of $5441 \mathrm{Ci}$ on October 12, 2020, while the dosimeter measurement temperature and humidity were $28^{\circ} \mathrm{C}$ and $59 \%$, respectively. The results showed that the error ranges at a wavelength of $651 \mathrm{~nm}$, $603 \mathrm{~nm}$, and $640 \mathrm{~nm}$ were $11 \%$ to $31 \%, 7 \%$ to $21 \%$, and $640 \mathrm{~nm}$ is $2 \%$ to $11 \%$, respectively.

The error variation could be influenced by the humidity, irradiation temperature, and the distance between the irradiation and the measurement. Harwell Amber and Red Perspex are clear/colorless PMMA (polymethyl methacrylate) dosimeters that capture radiation and change the absorbance value of the PMMA material. The result was used to obtain the specific absorbance value (absorbance per thickness $(\mathrm{cm})$ ), which possibly be affected by 
high humidity or temperature changes that cause condensation on the material. Furthermore, if the distance and time between irradiation and measurement are long, the radiation trapped in the PMMA material escapes, affecting the specific absorbance. The value was converted into the absorbed dose based on the calibration table, which is very specific because it has differences in each PMMA dosimeter production batch.

\section{CONCLUSION}

The experiment was conducted on 2 irradiator facilities using 2 Harwell Amber and 1 Red Perspex dosimeters. The Red Perspex dosimeter experimental results gave a more stable response in the 5-30 kGy dose range, which was caused by the 1 measurement wave $(640 \mathrm{~nm})$. Therefore, the consistency of the absorbed dose value was better than the Harwell Amber dosimeter. However, there is a need for further studies on the performance of the Harwell Amber and Red Perspex as routine dosimeters.

\section{REFERENCES}

1. IAEA, 2015, Technical Report Series no.48: Manual of Good Practice in Food Irradiation, Vienna.

2. INTERNATIONAL STANDART, 2011, ISO 14470: Food Irradiation-Requirement for the Development, Validation and Ruotine Control of the Process of Irradiation Using Ionizing Radiation for the Treatment of Food, Geneva: Swiss.

3. INTERNATIONAL STANDART, 2006, ISO 11137: Requirement for Development, Validation and Routine Control of a Sterilization Process for Medical Devices, Geneva: Swiss.

4. INTERNATIONAL STANDART, 2013, ISO 11137: Establishing of Sterilization Dose, Geneva: Swiss.

5. INTERNATIONAL STANDART, 2017, ISO 11137: Guidance of Dosimetric Aspects of Development, Validation and Routine Control, Geneva: Swiss.

6. R. G. Aghoyeh, H. Khalafi, "Design of dual-column water purification system for industrial gamma irradiator based of PUROLITE resins," Journal Annals of Nuclear Energy Series 69, pp. 90-96, 2014.
7. K. Manai, B. Askri, A. Loussaief, A. Trabelsi, "Evaluation Using GEANT4 of transit dose in Tunisian Gamma Irradiator for Insect Sterilization," Journal Applied Radiation and Isotopes, pp. 701-707, 2007.

8. V. Drndarevic, "Control of Gamma Irradiation Facility with Improved Safety System," Journal of Nuclear Science and Technology, vol. 45(4), pp. 361-367, 2012.

9. K. Elhamdi, K. Manai, M. Bhar, "Dose Calculation Using Tchebyshev Wavelets with Buildup Correction in The Tunisian Gamma Irradiator," Journal Radiation Physics and Chemistry, vol. 150, pp. 46-50, 2018.

10. M. D. F. Mortuza, L. Lapore, K. Khedkar, S. Thangam, A. Nahar, H. M. Jamil, L. Bandi, Md. K. Alam, "Commisioning Dosimetry and In Situ Dose Mapping of Semi Industrial Cobalt-60 Gamma Irradiation Facility Using Fricke and Ceric Cerous Dosimetry System and Comparison with Monte Carlo Simulation Data," Journal Radiation Physics, and Chemistry, 2017.

11. N. S. Pamungkas, R. B. Cahyono, D. Swantomo, "Penilaian Safety Integrity Level Iradiator Gamma Kategori-IV Pada Kegagalan Sistem Crane Pengontrol Sumber Zat Radioaktif," Jurnal Forum Nuklir, vol. 12(1), pp. 1-6, 2018.

12. O. Nugroho, S. Putra, N. A. Kundari, "Prarancang Unit Pengolahan Limbah Cair Pabrik Jeans Dengan Teknologi Iradiasi Gamma," Jurnal Forum Nuklir, vol. 13(2), pp. 63-72, 2019. 
Jurnal Forum Nuklir Volume 15, Nomor 1, Mei 2021 